\title{
Spatiotemporal dynamics of soil phosphorus and crop uptake in global cropland during the 20th century
}

\author{
Jie Zhang ${ }^{1}$, Arthur H. W. Beusen ${ }^{2,3}$, Dirk F. Van Apeldoorn ${ }^{2,4}$, José M. Mogollón ${ }^{2}$, Chaoqing Yu ${ }^{1}$, and \\ Alexander F. Bouwman ${ }^{2,3}$ \\ ${ }^{1}$ Department of Earth System Science, Tsinghua University, Beijing, 100084, China \\ ${ }^{2}$ Department of Earth Sciences-Geosciences, Faculty of Geosciences, Utrecht University, P.O. Box 80021, \\ 3508 TA Utrecht, the Netherlands \\ ${ }^{3}$ PBL Netherlands Environmental Assessment Agency, P.O. Box 30314, 2500 GH The Hague, the Netherlands \\ ${ }^{4}$ Farming Systems Ecology, Wageningen University, P.O. Box 430, 6700 AK Wageningen, the Netherlands \\ Correspondence to: Chaoqing Yu (chaoqingyu@tsinghua.edu.cn) and Alexander F. Bouwman (a.f.bouwman@uu.nl)
}

Received: 13 December 2016 - Discussion started: 4 January 2017

Revised: 15 March 2017 - Accepted: 17 March 2017 - Published: 20 April 2017

\begin{abstract}
Phosphorus (P) plays a vital role in global crop production and food security. In this study, we investigate the changes in soil $\mathrm{P}$ pool inventories calibrated from historical countrywide crop $P$ uptake, using a 0.5 -by- $0.5^{\circ}$ spatially explicit model for the period 1900-2010. Globally, the total $\mathrm{P}$ pool per hectare increased rapidly between 1900 and 2010 in soils of Europe $(+31 \%)$, South America $(+2 \%)$, North America $(+15 \%)$, Asia $(+17 \%)$, and Oceania $(+17 \%)$, while it has been stable in Africa. Simulated crop P uptake is influenced by both soil properties (available $\mathrm{P}$ and the $\mathrm{P}$ retention potential) and crop characteristics (maximum uptake). Until 1950, P fertilizer application had a negligible influence on crop uptake, but recently it has become a driving factor for food production in industrialized countries and a number of transition countries like Brazil, Korea, and China. This comprehensive and spatially explicit model can be used to assess how long surplus $\mathrm{P}$ fertilization is needed or how long depletions of built-up surplus $\mathrm{P}$ can continue without affecting crop yield.
\end{abstract}

\section{Introduction}

The current world population of 7.3 billion is expected to reach 9.7 billion in 2050 (UN, 2016), likely triggering a greater demand for food and resources. Moreover, increasing prosperity will lead to further shifts in human diets towards more meat and milk consumption, particularly in develop- ing countries (Alexandratos and Bruinsma, 2012). Livestock products require more nutrients for production compared to crops and thus may induce additional nutrient demands (Bouwman et al., 2013).

Phosphorus (P) is one of the major limiting nutrients in agriculture (Koning et al., 2008), which, unlike nitrogen, cannot be fixed from the atmosphere by living organisms or industrial processes. In early agricultural systems, P was supplied to soils by recycling animal manure, crushed animal bones, human excreta, city waste, and ash (Beaton, 2006). Since the industrial revolution, however, soil $P$ enrichment has been increasingly dominated by non-renewable $P$ resources such as guano (accumulated seabird droppings) and phosphate rock. Presently, phosphate rock provides the $\mathrm{P}$ for producing $90 \%$ of global $\mathrm{P}$ fertilizer use, which was 18.8 Tg P (Tg: teragram; $1 \mathrm{Tg}=10^{12} \mathrm{~g}=1$ million metric tons) in 2010 (PotashCorp, 2016). Yet this resource is rapidly dwindling, with estimates for phosphate rock availability ranging from peak $\mathrm{P}$ production in 2033 with subsequent rapid decline (Cordell et al., 2009) to half of the resources being used by 2100 (Van Vuuren et al., 2010), or complete exhaustion within the next 300-400 years (Van Kauwenbergh, 2010)

The availability of $\mathrm{P}$ for plant roots is determined by the concentration of phosphate ions in the soil solution and the ability of the soil to replenish them after plant uptake (Syers et al., 2008). The replenishing of phosphate ions depends on soil characteristics such as mineralogy, soil reaction, and de- 
Table 1. Comparison between non-spatial DPPS (Sattari et al., 2012) and the spatially explicit DPPS model.

\begin{tabular}{lll}
\hline Property & $\begin{array}{l}\text { Non-spatial DPPS model } \\
\text { (Sattari et al., 2012) }\end{array}$ & Spatially explicit model \\
\hline Spatial resolution & Continental & $0.5^{\circ}$ \\
Land use changes & No & Considering arable land expansion \\
Variable budget of soil P & Fixed & Recalculated every year \\
Initialization of soil pools & No & Initialized the soil pools for the pre-industrial period \\
Crop P uptake & Fixed fraction & Michaelis-Menten kinetics \\
P flow $(\mu$ LS and $\mu \mathrm{SL})$ & Fixed number & Calculated for every grid cell \\
Erosion and runoff & Fixed number & Changed with the pool size \\
Soil properties & One class in continental level & Grid-based resolution \\
\hline
\end{tabular}

gree of weathering (Fairhurst et al., 1999). Soil materials rich in soluble alumina or iron, a high-calcium activity, or clay minerals like kaolinite react with $\mathrm{P}$ to form insoluble compounds inaccessible to plant roots (Brady, 1990). Any surplus $\mathrm{P}$ application over crop uptake and losses by runoff and erosion accumulates in the soil as "residual P", which can be available for crop uptake for many years depending on the soil characteristics and management (Syers et al., 2008; Batjes, 2011). As long as adequate $P$ is present in the readily available pools to maintain a critical threshold $\mathrm{P}$ concentration in the soil solution, good crop yields can be maintained (Syers et al., 2008). Annual P inputs from fertilizer should compensate plant $\mathrm{P}$ uptake and erosion loss. However, when the amount of readily available $\mathrm{P}$ is below this critical threshold level, the rate of $\mathrm{P}$ release from residual $\mathrm{P}$ is insufficient to sustain optimal crop yields. Improving our mechanistic understanding of soil P dynamics locally and globally is important for evaluating broad-scale food security and improving sustainable P management.

This paper presents a global, spatially explicit analysis of soil $\mathrm{P}$ dynamics in global crop production systems using a soil model with two P pools (Wolf et al., 1987; Janssen et al., 1987), which was later presented as the "Dynamic Phosphorus Pool Simulator" (DPPS) (Sattari et al., 2012). DPPS describes the impact of long-term $P$ application on the transfers between a stable and a labile soil P pool as well as crop $\mathrm{P}$ uptake, accounting for weathering, deposition, and erosion (Fig. 1). The original model was developed for the field scale (Wolf et al., 1987; Janssen et al., 1987) and has recently been applied to simulate the impact of soil residual $\mathrm{P}$ on crop uptake and future demand for fertilizer $\mathrm{P}$ on the continental scale (Sattari et al., 2012). Compared with previous studies, our model has been improved to include spatially explicit calculations, land use change, dynamic transfer between different soil $\mathrm{P}$ pools, initialization of the $\mathrm{P}$ pools with global observations, dynamic $\mathrm{P}$ loss by runoff, dynamic calculation of crop P uptake, and time-variant maximum uptake parameter (Table 1). Since build-up of residual $\mathrm{P}$ is a local process but with global consequences, the aim of this paper is to ultimately simulate the soil $\mathrm{P}$ dynamics, soil P fertility, and crop
P uptake for global cropland from the beginning of the 20th century up until the year 2010 at a $0.5 \times 0.5^{\circ}$ spatial scale.

\section{Material and methods}

\subsection{Model description}

The spatially explicit DDPS model presented here describes the $\mathrm{P}$ dynamics in croplands as a function of two soil $\mathrm{P}$ pools, a labile soil $\mathrm{P}$ pool $\left(L P, \mathrm{~kg} \mathrm{Pha}^{-1}\right)$, and a stable soil $\mathrm{P}$ pool $\left(S P, \mathrm{~kg} \mathrm{Pha}^{-1}\right)$ with an annual temporal scale and a spatial resolution of 0.5 by $0.5^{\circ}$ (Fig. 1). LP represents all forms of $\mathrm{P}$ that can directly be taken up by plant roots, comprising both organic and inorganic P; SP represents forms of P bound to soil minerals and organic matter that are not directly available to plants (Table 2). $\mathrm{P}$ is transferred in both directions between the two pools.

Our model considers natural $\mathrm{P}$ inputs to the soil i.e. weathering (weathering, $\mathrm{kgPha}^{-1}$ year $^{-1}$ ), litter (litter, $\mathrm{kg} \mathrm{Pha}^{-1}$ year $\left.^{-1}\right)$, and atmospheric deposition (deposition, $\mathrm{kgPha}^{-1}$ year $^{-1}$ ) - and anthropogenic $\mathrm{P}$ inputs, including application of mineral $\mathrm{P}$ fertilizer (fertilizer, $\mathrm{kgPha}^{-1}$ year $^{-1}$ ) and animal manure (manure, $\mathrm{kgPha}^{-1}$ year $\left.^{-1}\right)$. P outflows from the soil system include the withdrawal of $\mathrm{P}$ in harvested crops (uptake, $\mathrm{kg} \mathrm{Pha}^{-1}$ year $^{-1}$ ) and runoff (runoff, $\mathrm{kg} \mathrm{Pha}^{-1}$ year $^{-1}$ ) (Fig. 1; Table 2).

The thickness of the topsoil is assumed constant at $30 \mathrm{~cm}$; soil loss by runoff is replaced at the bottom of the topsoil by fresh subsoil material from below $30 \mathrm{~cm}$ (fresh_soil, $\mathrm{kg} \mathrm{Pha}^{-1}$ year $^{-1}$ ). The proportion of LP and SP in fresh_soil is based on the pools according to the soil $\mathrm{P}$ inventory depicted in Yang et al. (2013). The P input from litter $\left(\mathrm{kg} \mathrm{Pha}^{-1}\right.$ year $\left.^{-1}\right)$ remaining after crop harvest is returned to the soil and becomes part of the LP pool. For natural ecosystems, assuming there is no anthropogenic fertilizer application, the uptake equals the inputs from litter, deposition, and weathering. In contrast, $\mathrm{P}$ uptake in agricultural soils is calculated explicitly (see below). 


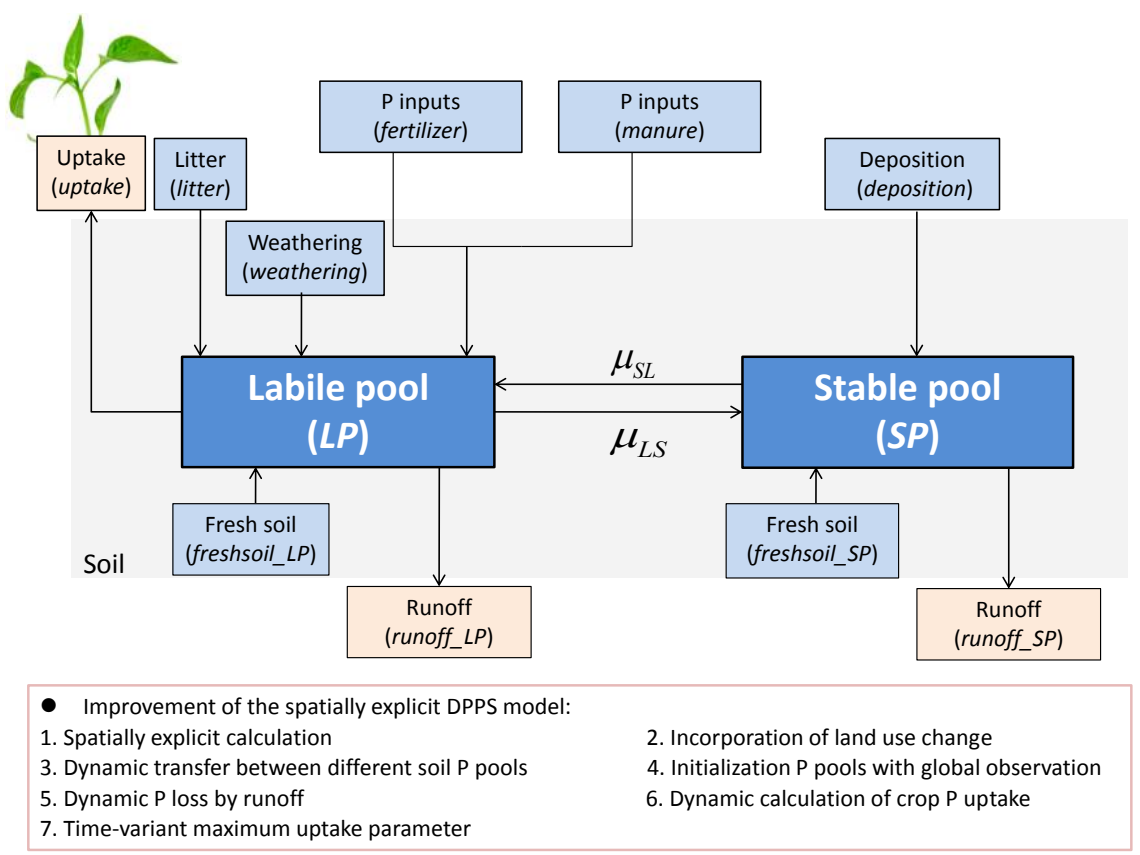

Figure 1. Scheme of the DPPS model. The model includes two dynamic P pools, i.e. the labile pool (LP) and the stable pool (SP), comprising both organic and inorganic P. Five inputs of $\mathrm{P}$ to the system are defined: mineral fertilizer and manure, weathering, deposition, fresh soil, and litter. $\mu_{\mathrm{LS}}$ and $\mu_{\mathrm{SL}}$ (years) denote the transfer time of P from LP to SP and from SP to LP, respectively. Modified from Sattari et al. (2012).

P from atmospheric deposition obtained from the Model of Atmospheric Transport and Chemistry (MATCH) is assumed to be a direct input for the SP pool only, since mineral aerosols (dust) are the dominant source of atmospheric $\mathrm{P}(\sim 82 \%)$ (Mahowald et al., 2008) and are not readily available for plant uptake. $\mathrm{P}$ from weathering in global cropland is assumed to amount to $1.6 \mathrm{Tg}_{\mathrm{gear}}{ }^{-1}$ (Liu et al., 2008). This value is used to calculate the weathering fraction of the soil $\mathrm{P}$ in apatite $\left(f r_{-}\right.$weathering $\left.=0.001747\right)$ from the global natural soil P inventory by Yang et al. (2013), and it is assumed to be available directly for plant uptake.

The global spatially explicit $P$ runoff is calculated following the approach of Beusen et al. (2015), who distinguished losses from recent nutrient applications in the form of fertilizer, manure, or organic matter (Hart et al., 2004), and a "memory" effect related to long-term historical changes in soil nutrient inventories (McDowell and Sharpley, 2001; Tarkalson and Mikkelsen, 2004). The memory effect is based on Cerdan et al. (2010) using slope, soil texture, and land cover type to estimate country-aggregated soil-loss rates for arable land, grassland, and natural vegetation. The $\mathrm{P}$ content of the soil loss (runoff_LP and runoff_SP) is based on the LP and SP of the soil in the grid cell considered at that moment in time.

The yearly changes of the LP and SP pools $\left(\mathrm{kg} \mathrm{Pha}^{-1}\right.$ year $\left.^{-1}\right)$ are calculated as follows:

$$
\begin{aligned}
& \frac{\partial_{\mathrm{LP}}}{\partial_{t}}=F_{\mathrm{sp} 21 \mathrm{p}}-F_{\mathrm{lp} 2 \mathrm{sp}}+\text { weathering }+ \text { fertilizer }+ \text { manure } \\
& \quad+\text { freshsoil_LP }+ \text { litter }- \text { runoff_LP }- \text { uptake, } \\
& \frac{\partial_{\mathrm{SP}}}{\partial_{t}}=F_{\mathrm{lp} 2 \mathrm{sp}}-F_{\mathrm{Sp} 21 \mathrm{p}}+\text { deposition }+ \text { freshsoil_SP } \\
& \quad-\text { runoff_SP },
\end{aligned}
$$

where $F_{\mathrm{lp} 2 \mathrm{sp}}$ and $F_{\mathrm{sp} 2 \mathrm{lp}}\left(\mathrm{kgPha}^{-1} \mathrm{year}^{-1}\right)$ are the fluxes from LP to SP and SP to LP, respectively:

$$
\begin{aligned}
& F_{\text {lp2sp }}=\frac{\mathrm{LP}}{\mu_{\mathrm{LS}}}, \\
& F_{\mathrm{sp} 21 \mathrm{p}}=\frac{\mathrm{SP}}{\mu_{\mathrm{SL}}},
\end{aligned}
$$

where the variables $\mu_{\mathrm{LS}}$ and $\mu_{\mathrm{SL}}$ are transfer times (years) from LP to SP and SP to LP, respectively. The transfer time $\mu_{\mathrm{SL}}$ from LP to SP is set to 5 years based on the original DPPS (Janssen et al., 1987). The transfer time from SP to LP $\left(\mu_{\mathrm{SL}}\right)$ is calculated for every grid cell based on the mass balance of LP for natural ecosystems using Eq. (1) and assuming steady state:

$\mu_{\mathrm{SL}}=\frac{\mathrm{SP}}{\mathrm{LP} \times \frac{1}{\mu_{\mathrm{LS}}}+\text { deposition }}$.

We selected the mass balance of LP to calculate $\mu_{\mathrm{SL}}$ (instead of that for SP) because it yields a value that matches the value obtained by Wolf et al. (1987) based on experimental data. 
Table 2. Model parameters of DPPS.

\begin{tabular}{|c|c|c|}
\hline Parameter & Description (unit) & Method/value/source \\
\hline fr_weathering & $\begin{array}{l}\text { Fraction of apatite in soils that is released dur- } \\
\text { ing weathering (no dimension) }\end{array}$ & 0.001747 \\
\hline weathering & $\begin{array}{l}\text { The annual amount of } \mathrm{P} \text { that becomes available } \\
\text { from the parent material }\left(\mathrm{kg} \mathrm{Pha}^{-1} \mathrm{year}^{-1}\right)\end{array}$ & $\begin{array}{l}\text { fr_weathering multiplied by the soil P present as apatite } \\
\text { according to Yang et al. (2013) }\end{array}$ \\
\hline deposition & $\begin{array}{l}\text { The annual amount of } \mathrm{P} \text { from atmospheric de- } \\
\text { position }\left(\mathrm{kg} \mathrm{Pha}^{-1} \text { year }^{-1}\right)\end{array}$ & $\begin{array}{l}\text { Modelled gridded } \mathrm{P} \text { deposition from Mahowald et } \\
\text { al. (2008) }\end{array}$ \\
\hline fertilizer & Fertilizer $\mathrm{P}$ input $\left(\mathrm{kg} \mathrm{Pha}^{-1}\right.$ year $\left.^{-1}\right)$ & Beusen et al. (2016) \\
\hline manure & Manure $\mathrm{P}$ input $\left(\mathrm{kg} \mathrm{Pha}^{-1}\right.$ year $\left.^{-1}\right)$ & Beusen et al. (2016) \\
\hline LP & $\begin{array}{l}\text { The LP pool, calculated for every grid every } \\
\text { year }\left(\mathrm{kg} \mathrm{Pha}^{-1}\right)\end{array}$ & Eq. (1) \\
\hline SP & $\begin{array}{l}\text { The SP pool, calculated for every grid every } \\
\text { year }\left(\mathrm{kg} \mathrm{Pha}^{-1}\right)\end{array}$ & Eq. (2) \\
\hline LP_yang & The initial labile pool size & Yang et al. (2013) \\
\hline SP_yang & The initial stable pool size & Yang et al. (2013) \\
\hline max_uptake & $\begin{array}{l}\text { The maximum amount of uptake by plants from } \\
\text { availableP }\left(\mathrm{kg} \mathrm{Pha}^{-1} \text { year }^{-1}\right)\end{array}$ & $\begin{array}{l}\text { Changes with time. The upper limit of max_uptake is } \\
100\end{array}$ \\
\hline init_recovery & $\begin{array}{l}\text { The initial recovery fraction, which is the slope } \\
\text { of the } \mathrm{P} \text { response curve at zero availableP, spe- } \\
\text { cific per soil type (no dimension) }\end{array}$ & Batjes (2011) \\
\hline fr_mobile & $\begin{array}{l}\text { The calibration coefficient, which mimics the } \\
\text { direct } \mathrm{P} \text { availability within the labile pool }\end{array}$ & Eq. (7) \\
\hline availableP & $\begin{array}{l}\text { The amount of } \mathrm{P} \text { available to plant roots } \\
\left(\mathrm{kg} \mathrm{Pha}^{-1} \text { year }^{-1}\right)\end{array}$ & fr_mobile $\times$ LP \\
\hline litter & $\begin{array}{l}\text { The } \mathrm{P} \text { content in crop litter that returns to the } \\
\text { soil }\left(\mathrm{kg} \mathrm{Pha}^{-1} \text { year }^{-1}\right)\end{array}$ & $\begin{array}{l}\text { Soils under natural vegetation: see text } \\
\text { Arable soil: } 0\end{array}$ \\
\hline$\mu_{\mathrm{LS}}$ & Transfer time for LP to SP (years) & Eq. (5) (Sattari et al., 2012) \\
\hline$\mu_{\mathrm{SL}}$ & Transfer time for SP to LP (years) & Eq. (5) \\
\hline uptake & Crop P uptake $\left(\mathrm{kg} \mathrm{Pha}^{-1}\right.$ year $\left.^{-1}\right)$ & $\begin{array}{l}\text { Soils under natural vegetation: the inputs from litter, de- } \\
\text { position, and weathering } \\
\text { Arable soil: Eq. (6) }\end{array}$ \\
\hline agri_2_natural_years & $\begin{array}{l}\text { The years for abandoned land to revert to natu- } \\
\text { ral conditions }\end{array}$ & 30 \\
\hline
\end{tabular}

The amount of $\mathrm{P}$ that can be accessed by plant roots (availableP, $\mathrm{kg} \mathrm{Pha}^{-1}$ year $^{-1}$ ) is calculated as a fraction of LP $\left(f r_{-}\right.$mobile $\left.\times L P\right)$. The $\mathrm{P}$ uptake by crops was calculated using Michaelis-Menten kinetics (Michaelis and Menten, 1913; for elaboration for nutrient uptake see Nijland et al., 2008) as follows:

uptake $=\frac{\text { max_uptake } \times \text { availableP }}{\left(\frac{c \times \text { max_uptake }}{\text { init_recovery }+ \text { availableP }}\right)}$,

where max_uptake $\left(\mathrm{kg} \mathrm{Pha}^{-1}\right.$ year $\left.^{-1}\right)$ is the maximum $\mathrm{P}$ uptake; init_recovery is the initial recovery fraction (no dimension), which is the initial slope of the $\mathrm{P}$ response curve presented (Batjes, 2011) for all soil types distinguished in the legend of the FAO-Unesco soil map of the world (FAOUnesco, 1974); and $c$ is a constant to obtain the availableP for which uptake is 0.5 times max_uptake (no dimension; $c=0.5$ ). The calculation of the area-weighted value of init_recovery for each grid cell is based on the sub-grid distribution of soil classes.
Max_uptake is a time-dependent variable, considering the development of technology in crop production. There are two rules: the first is that max_uptake is not allowed to decrease. A second condition is that max_uptake have a maximum value of $100 \mathrm{~kg} \mathrm{Pha}^{-1}$ year $^{-1}$, which exceeds the presentday highest value for all countries of the world based on our data (Sect. 2.2). We make a split in 1961, the year in which the FAO data series start (FAO, 2016a, b). Prior to 1961 max_uptake is the minimum of twice the uptake calculated from crop production data for 1960, and the sum of $\mathrm{P}$ inputs from fertilizers and manure; from 1961 onwards, it is the uptake calculated from crop production data times a factor of 2, or the previous max_uptake if that is larger.

In grid cells where cropland expansion takes place, the initial conditions of virgin soil (without fertilizer history) are assigned to the new, additional area in the year considered. For land abandonment (arable land to natural land) we assume that it takes 30 years for abandoned land to revert to natural conditions, and in this period the $\mathrm{P}$ in litter increases and 
uptake decreases linearly with time from zero to the natural flux.

\subsection{Data used}

We use the spatially explicit data on $\mathrm{P}$ fertilizer use and animal manure spreading, land use, crop production, and cropland areas from the database used in the IMAGE-Global Nutrient Model (GNM) (Beusen et al., 2016). In this database, for the period 1900-1960, the gridded inventories of $\mathrm{P}$ inputs from a recent study (Bouwman et al., 2013) were used for the calculation of the soil $\mathrm{P}$ pools and crop uptake. This dataset was based on various sources for land use (Klein Goldewijk et al., 2011, 2010), livestock for 1900-1960 (Mitchell, 1998, 1993a, b), animal and crop production and fertilizer use for 1930-1950 (FAO, 1951), and fertilizer use prior to 1930 (Cressy Morrison, 1937), which were spatially distributed with IMAGE-GNM as described by Bouwman et al. (2013). Due to the lack of data during this time period, uptake estimates are more uncertain than those for the years from 1961 to 2010 based on FAO statistics (see below).

Crop $\mathrm{P}$ uptake and fertilizer inputs per hectare are spatially homogeneous for all grid cells with cropland within each country. The total production of $\mathrm{P}$ from animal manure was estimated from country livestock data for non-dairy and dairy cattle, pigs, poultry, sheep, and goats, and the P content in the manure (Table S2 in the Supplement). The amount of manure available for spreading in agricultural land excludes droppings in grassland, manure used as fuel or building material, or manure otherwise ending outside the agricultural system (e.g. in lagoons) (Beusen et al., 2016).

IMAGE-GNM distinguishes two crop systems, i.e. (1) crops in mixed systems, in which there is a linkage between crop and livestock production through manure (from animals to crops) and feed (from crops to animals) exchanges, and (2) crops in pastoral systems, in which crop and livestock production are separate systems. While $\mathrm{P}$ fertilizers are the same in all cropland within a country, $\mathrm{P}$ inputs from animal manure are different in mixed and pastoral systems.

For the period 1960 to 2010, simulated crop P uptake is validated against $\mathrm{P}$ in harvested crop production data covering all (> 120) annual and perennial food, feed, and fodder crops and fruits from FAO statistics (FAO, 2016a, b) and are aggregated into 34 crop groups distinguished in recent FAO studies (Alexandratos and Bruinsma, 2012). The historical P uptake per hectare is calculated from the crop yields from the above-mentioned FAO statistics for 34 crop groups and $\mathrm{P}$ content for each crop group, as listed in Table S3.

We present the data and results for a number of individual countries (China, United States, South Africa, and France) and world regions. The definition of the regions is provided in Table S1.

\subsection{Initialization and calibration}

To initialize the model in 1900 , we assume that the $\mathrm{P}$ pools are in equilibrium. We furthermore assume that and the sum of LP and SP equals the total P (TP) in natural systems proposed by Yang et al. (2013), representing the pre-industrial conditions. Model simulations are run until 2010 for the entire globe using the data stipulated in Sect. 2.2. The model is then calibrated by varying fr_mobile to achieve a good fit with the crop uptake data for each country using an iterative procedure to minimize the difference between model result and the uptake based on crop production data (see Sect. 2.2) by modifying fr_mobile (see Eq. 6). First, the country-specific error $\left(\mathrm{kg} \mathrm{Pha}^{-1}\right.$ year $\left.^{-1}\right)$ in the modelled $\mathrm{P}$ uptake is calculated:

error $=\frac{\sum_{1}^{n}\left(\text { uptake }_{\text {model }}-\text { uptake }_{\text {data }}\right)}{n}$,

where $n$ is the number of data points between 1960 and 2010. We compare every second year, so $n=26$. fr_mobile is limited to the range $[0.01,0.7]$. The calibration is considered successful when the absolute value of the error is less than 0.4 . For countries where the calibration is not successful, we apply the regional (Table S1) average area-weighted fr_mobile. Once the optimal fr_mobile has been estimated, we use the normalized root mean square error (NRMSE) to compare simulated and measured P uptake (see Sect. S1).

\subsection{Sensitivity analysis}

The model sensitivity is investigated using Latin hypercube sampling (LHS), with uncertainty ranges for 12 model parameters (Table 3 ) and expressed as the standardized regression coefficient $(S R C)$, to show the influence of model parameters to model output. We focused on the sensitivity of model parameters to modelled LP and SP size, and crop P uptake for 2 years (1950 and 2000). A detailed description of the approach for the sensitivity analysis and the results is in Sect. S2 in the Supplement.

\section{Results}

\subsection{P inputs and uptake}

The global $\mathrm{P}$ inputs (including mineral fertilizer and manure) increased from 2.0 Tg P in 1900 to $23.0 \mathrm{Tg} \mathrm{P}$ in 2010 with large variations across different regions and countries of the world. Between 1900 and 2010, the global use of mineral fertilizer in croplands increased from $0.4 \mathrm{Tg}$ to $15.8 \mathrm{Tg}_{\text {year }}{ }^{-1}$ and the use of manure from $1.6 \mathrm{Tg}$ to 7.2 $\mathrm{Tg}$ year $^{-1}$. At the global scale, about half of the applied $\mathrm{P}$ in 2010 was taken up by harvested crops (modelled: 12 Tg P year ${ }^{-1}$, $7.3 \mathrm{~kg} \mathrm{Pha}^{-1}$ year $^{-1}$; data: $13.8 \mathrm{Tg} \mathrm{P}_{\text {year }}{ }^{-1}$, $8 \mathrm{~kg} \mathrm{Pha}^{-1}$ year $\left.^{-1}\right)$. All world regions and countries show 
Table 3. The parameters included in the sensitivity analysis.

\begin{tabular}{lrrrl}
\hline Symbol & Min & Default & Max & Type \\
\hline$\mu_{\text {LS }}$ & 3 & 5 & 7 & Range \\
fr_weathering & 0.0014 & 0.001747 & 0.0021 & Range \\
agri_2_natural_years & 10 & 30 & 50 & Range \\
max_uptake & 0.75 & 1 & 1.25 & Multiplier \\
fr_mobile & 0.75 & 1 & 1.25 & Multiplier \\
LP_yang & 0.75 & 1 & 1.25 & Multiplier \\
TP_yang & 0.75 & 1 & 1.25 & Multiplier \\
deposition & 0.75 & 1 & 1.25 & Multiplier \\
init_recovery & 0.75 & 1 & 1.25 & Multiplier \\
runoff & 0.75 & 1 & 1.25 & Multiplier \\
fertilizer & 0.75 & 1 & 1.25 & Multiplier \\
manure & 0.75 & 1 & 1.25 & Multiplier \\
\hline
\end{tabular}

similar patterns before 1950 , i.e. very low $\mathrm{P}$ input levels and crop $\mathrm{P}$ uptakes that do not differ much from the inputs.

The annual $\mathrm{P}$ inputs in western Europe increased from $0.4 \mathrm{TgP}$ in 1900 to $2 \mathrm{TgP}$ in 1980 and then decreased to $0.9 \mathrm{TgP}$ in 2010 , which translates into rates of $24 \mathrm{~kg} \mathrm{Pha}^{-1}$ year $^{-1}$ in 1980 , followed by a gradual decrease to $11 \mathrm{~kg} \mathrm{Pha}^{-1}$ year $^{-1}$ in 2010 (Fig. 2a). Crop uptake started to rapidly increase in western Europe from $4 \mathrm{~kg} \mathrm{Pha}^{-1}$ year $^{-1}$ in 1950 to $13 \mathrm{~kg} \mathrm{Pha}^{-1}$ year $^{-1}$ in 2010 ; in 2010, the crop $\mathrm{P}$ uptake exceeded the $\mathrm{P}$ fertilizer and manure application (Fig. 2a), and two levels of crop uptake have been achieved in different years at the same application rate (Fig. 4a and j, western Europe and France). This indicates that since the 1980s P application has been reduced, while uptake continues to increase due to the supply of residual soil P (Fig. 5a). The model results also show this hysteresis, although DPPS underestimates the P uptake in the most recent years (Fig. 2a).

Agriculture in western Europe is much more intensive than in the United States (Van Grinsven et al., 2015). P inputs in North America peaked in 1980 with a total of $2.9 \mathrm{Tg}$ year $^{-1}$. Application rates increased from $1 \mathrm{~kg} \mathrm{Pha}^{-1}$ in 1900 to $12 \mathrm{~kg} \mathrm{Pha}^{-1}$ year $^{-1}$ in 1980 and $10 \mathrm{~kg} \mathrm{Pha}^{-1}$ year $^{-1}$ in 2010, and crop P uptake lagged behind P inputs for around 20 years, but inputs and uptake are now at a similar level (Fig. 5b). The trend is visible in United States data, and DPPS results agree well with the uptake based on production data in both cases (Fig. $2 \mathrm{~h}$ and b).

In contrast to the other continents, the input level in Africa is much lower, with annual application rates ranging from $1 \mathrm{~kg} \mathrm{Pha}^{-1}$ year $^{-1}$ in 1900 to $5 \mathrm{~kg} \mathrm{Pha}^{-1}$ year $^{-1}$ in 2010 . Along with the slowly increasing application rates, African crop uptake is also increasing at a low rate with no accumulation of soil P (Fig. 5c). DPPS results are in good agreement with the production-based uptake for Africa (Figs. 2c and 3c).

The annual $\mathrm{P}$ application in Asia increased more than 12fold from $0.9 \mathrm{Tg}_{\text {year }}{ }^{-1}$ in 1900 to $12.4 \mathrm{Tg}_{\text {year }}{ }^{-1}$ in 2010 , (a) Western Europe

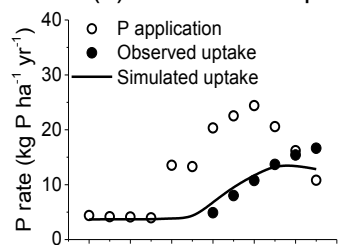

(c) Africa

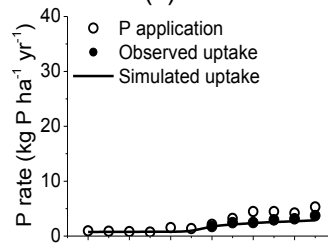

(e) South America

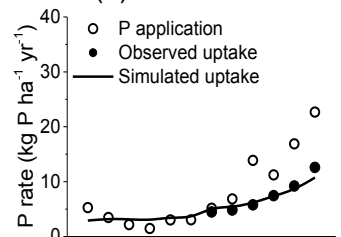

(g) China

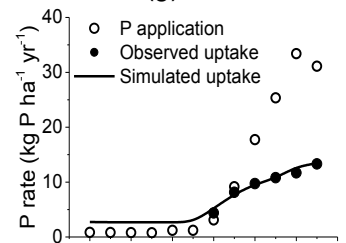

(i) South Africa
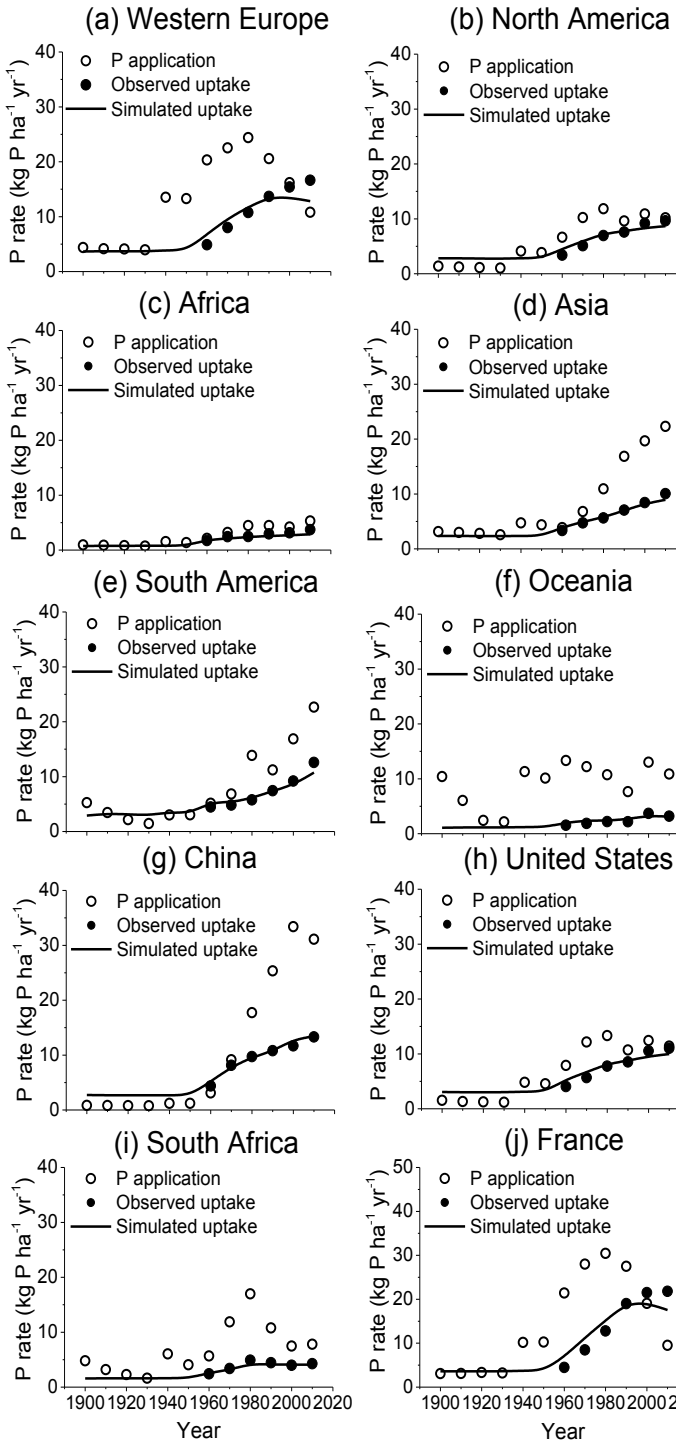

(d) Asia

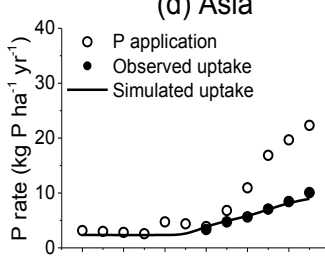

(f) Oceania

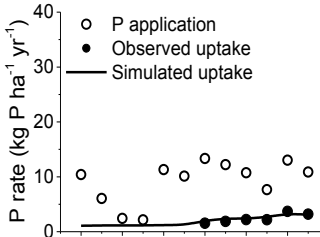

(h) United States

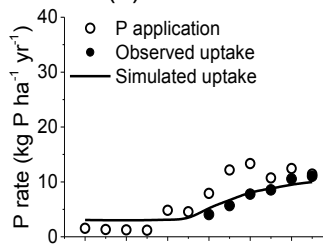

(j) France

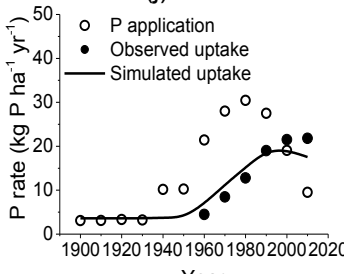

Year

Figure 2. Trends of annual $P$ application (including $P$ from manure and fertilizer), historical $\mathrm{P}$ uptake and simulated $\mathrm{P}$ uptake in cropland for the period 1900-2010 in the continents and world regions of western Europe (a), North America (b), Africa (c), Asia (d), South America (e), and Oceania (f), and the countries of China (g), the United States (h), South Africa (i), and France (j). Open and closed dots refer to $\mathrm{P}$ application, and observed $\mathrm{P}$ uptake rates from FAO validation data. Solid lines refer to simulated $\mathrm{P}$ uptake rates. Western Europe includes Andorra, Austria, Belgium, Denmark, the Faroe Islands, Finland, France, Germany, Gibraltar, Greece, Holy See (Vatican City State), Iceland, Ireland, Italy, Liechtenstein, Luxembourg, Monaco, the Netherlands, Norway, Portugal, San Marino, Spain, Svalbard and Jan Mayen, Sweden, Switzerland, and the United Kingdom. We can produce the results of every year; however, due to the space limitation, we only show the results of every 10 years from 1900 to 2010 . 

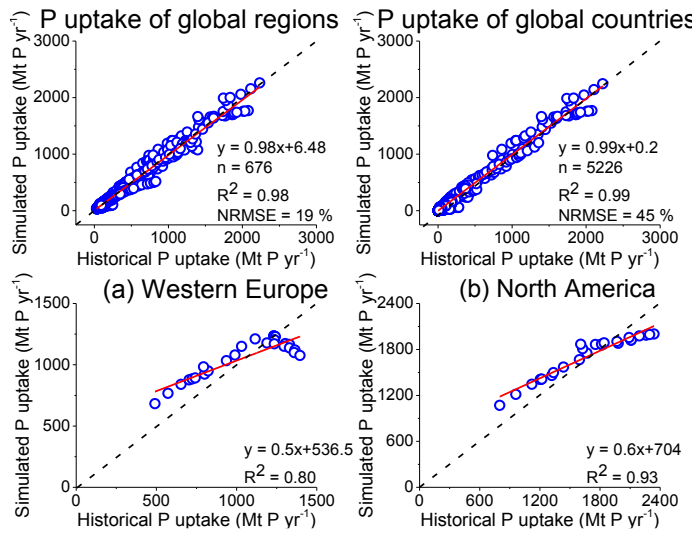

(c) Africa

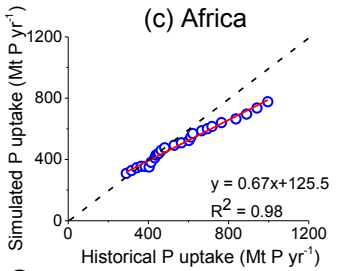

(e) South America

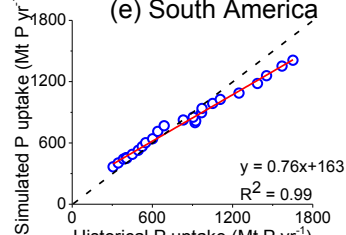

(g) China
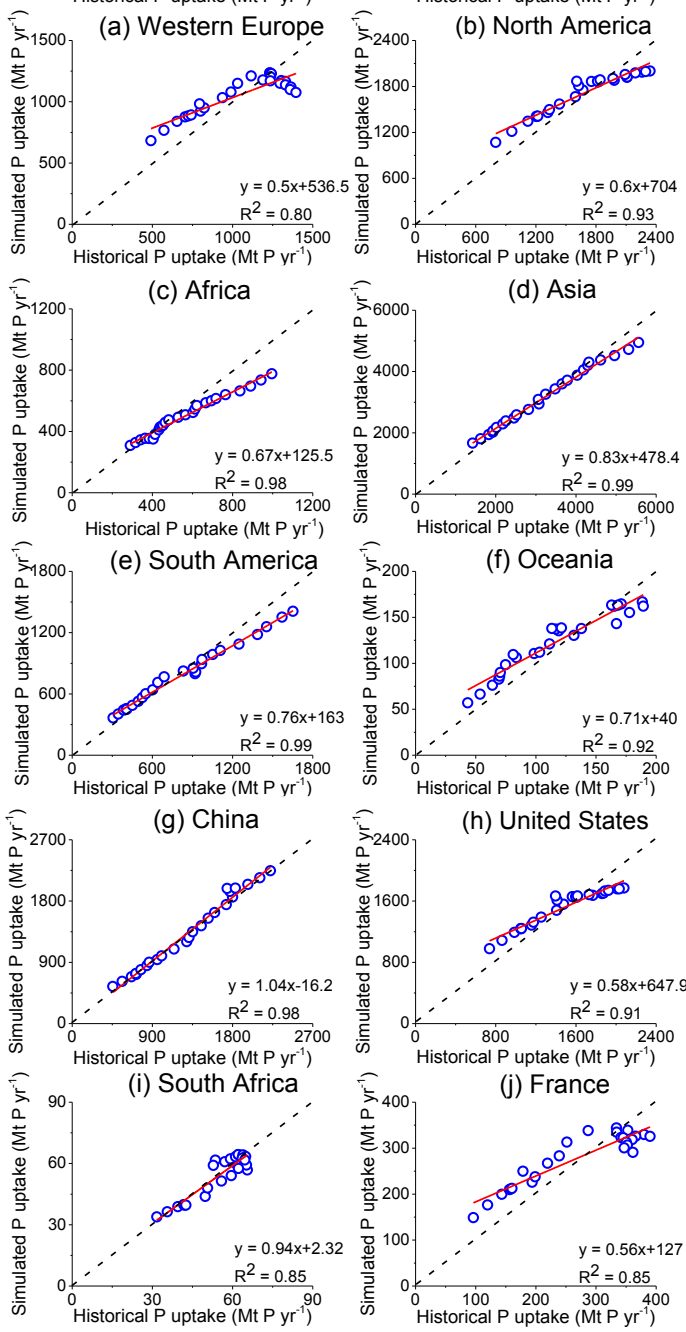

Figure 3. Relationship between simulated and historical $\mathrm{P}$ uptake for individual regions, countries, and the world, presenting results for every 2 years from 1961 to 2010 . Dashed line is $1: 1$.

and manure $\mathrm{P}$ more than doubled from 0.8 to $3.5 \mathrm{Tg}$ year $^{-1}$ from 1960 to 2010. The $\mathrm{P}$ application rates of Asia rose dramatically from low values in 1900 to $22 \mathrm{~kg} \mathrm{Pha}^{-1}$ year $^{-1}$ in 2010. Asia is currently in the phase of rapidly increasing inputs, with crop P uptake also increasing but at a slower rate (Fig. 2d). DPPS results are in good agreement with the uptake data for this continent (Figs. 2d and 3d).

In South America, the annual $\mathrm{P}$ inputs increased from 5 to $23 \mathrm{~kg} \mathrm{Pha}^{-1}$ year $^{-1}$ between 1900 and 2010 , and the annual $\mathrm{P}$ uptake also increased from 4 to $13 \mathrm{~kg} \mathrm{Pha}^{-1}$ year $^{-1}$ for the same period of time. Although DPPS underestimates (a) Western Europe

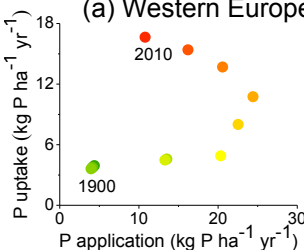

(b) North America 1900
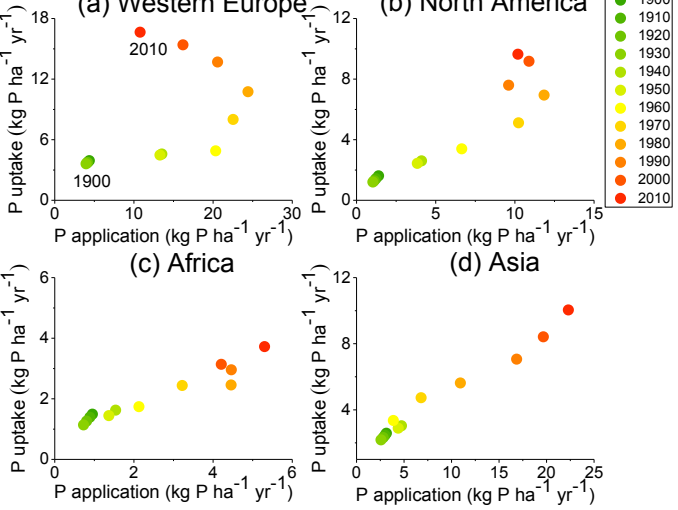

(d) Asia

(e) South America
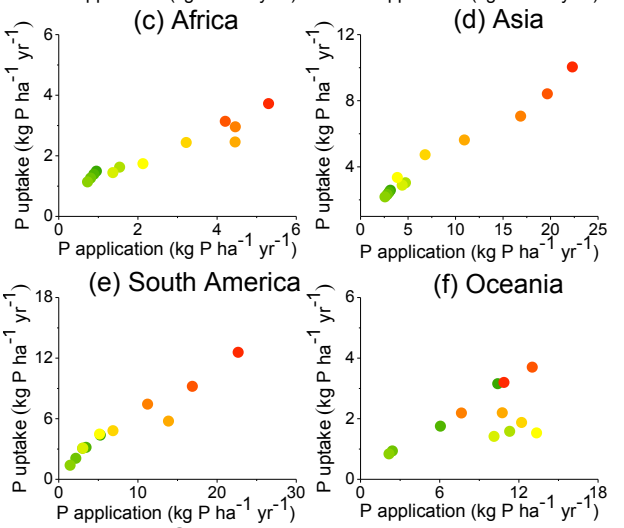

(f) Oceania
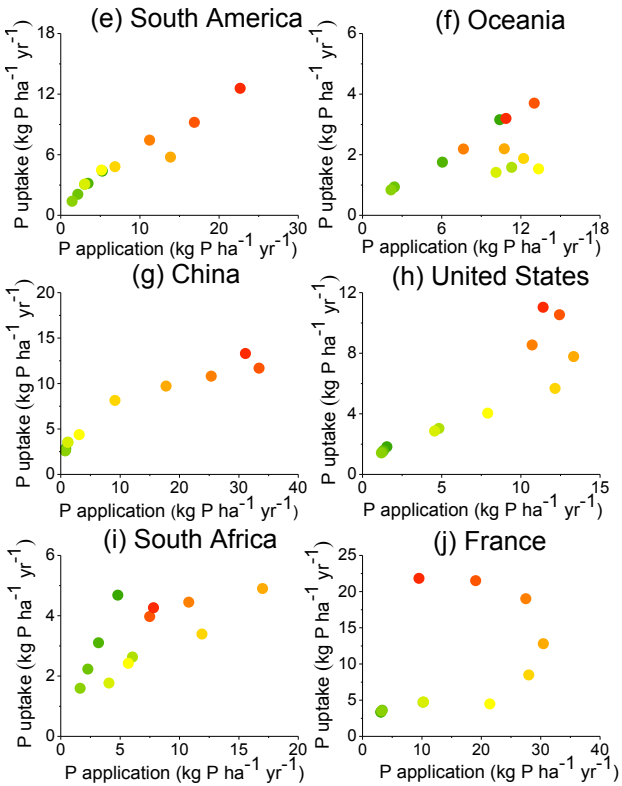

Figure 4. $P$ uptake vs. $P$ application between 1900 and 2010. The contribution of residual $\mathrm{P}$ to $\mathrm{P}$ uptake can be observed in western Europe (a) and France (j) as P uptake has steadily increased with time, yet $\mathrm{P}$ application has decreased since the 1980s.

the $\mathrm{P}$ uptake in recent years, the simulations agree with crop production data for most years (Figs. 2e and 3e).

In Oceania, annual $\mathrm{P}$ application varied between 10 and $13 \mathrm{~kg} \mathrm{Pha}^{-1}$ year $^{-1}$ in recent decades. Oceania shows low uptake rates relative to inputs over the whole period 1900 2010, and the simulated results are in good agreement with the data (Figs. $2 \mathrm{f}$ and $3 \mathrm{f}$ ). This indicates that the cumulative inputs of $\mathrm{P}$ fertilizer and manure exceed the crop $\mathrm{P}$ uptake.

The DPPS model adequately simulates $\mathrm{P}$ uptake by crops in different regions and countries (Fig. 2). The modelled $\mathrm{P}$ uptake values match well the historical records (Fig. 3) as shown by the NRMSE of $19 \%$ (26 regions, 26 year, 676 points). At the country scale, simulations and observations of annual $\mathrm{P}$ uptake for every second year (1960 2010) agree well (NRMSE $=45 \%$; 201 countries, 26 years, 5226 points). The NRMSE of the country-level simulation 
(a) Western Europe

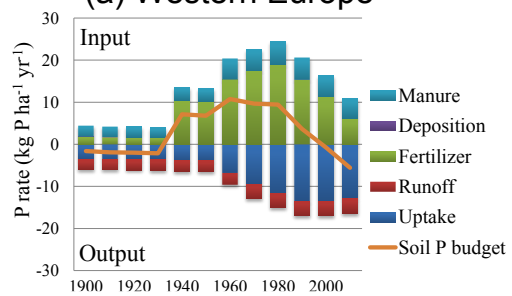

(c) Africa

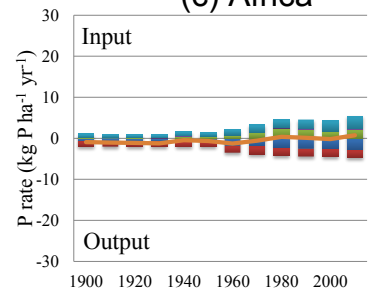

(e) South America

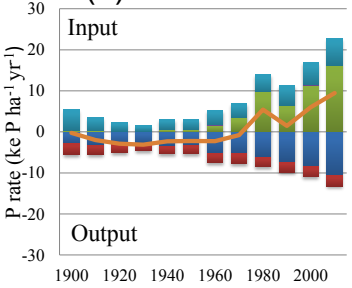

(g) China
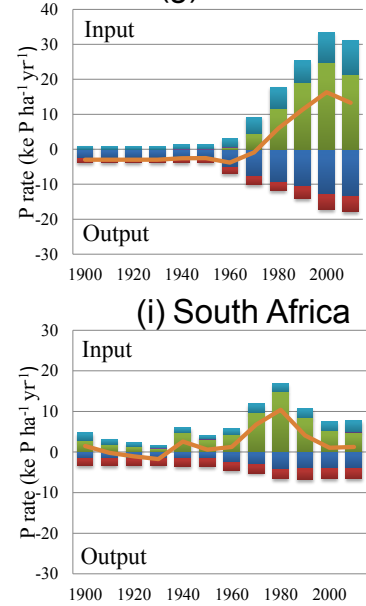

(b) North America

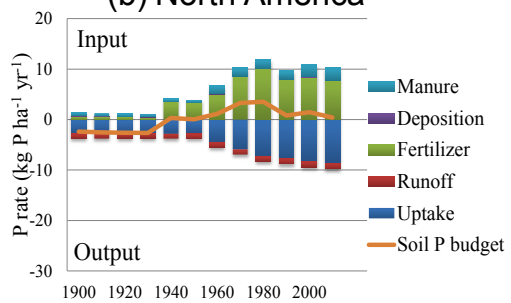

(d) Asia

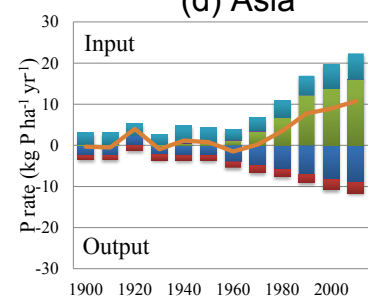

(f) Oceania

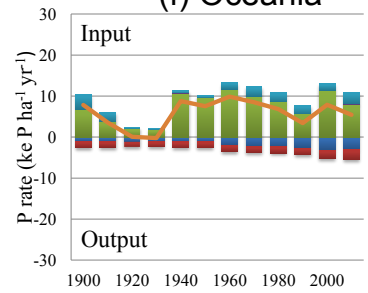

(h) United States

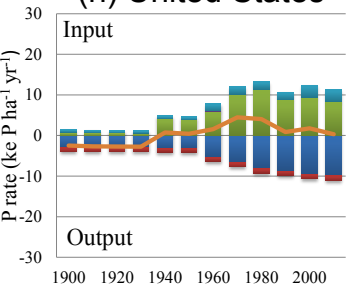

(j) France

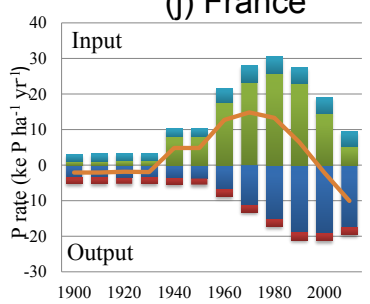

Figure 5. The total soil $\mathrm{P}$ inputs (fertilizer, manure, and deposition), soil $\mathrm{P}$ outputs (crop uptake and runoff), and biogeochemical soil $\mathrm{P}$ budget (soil P input - soil P output) of different regions and countries. Soil P inputs are positive and outputs are negative.

exceeds that of the aggregated results for world regions, which is caused by the underestimation of peak values by DPPS. However, for the global and regional scale we consider the DPPS results acceptable ( $<50 \%$ for global scale).

\subsection{Soil $\mathbf{P}$ budgets}

The soil $\mathrm{P}$ budget is defined as the biogeochemical soil $\mathrm{P}$ budget, which is the difference between soil P inputs (mineral fertilizer, manure, and deposition) and outputs (uptake and runoff) (Figs. 5 and 6a).
The soil budgets (Fig. 5) show the difference between the industrialized countries that are currently in an equilibrium or depletion phase with regard to soil $\mathrm{P}$, transition countries that are in an accumulation phase (e.g. China, India, and Brazil), and countries with a low input and productivity crop production system (e.g. Africa). The soil budgets also show how important runoff losses are for the budgets and for determining whether $\mathrm{P}$ is accumulating (Fig. 6a).

We also calculated the agronomic soil $\mathrm{P}$ budget, which is the difference between crop P uptake and inputs (the sum of fertilizer and manure) (Fig. S1c in the Supplement). The crop 

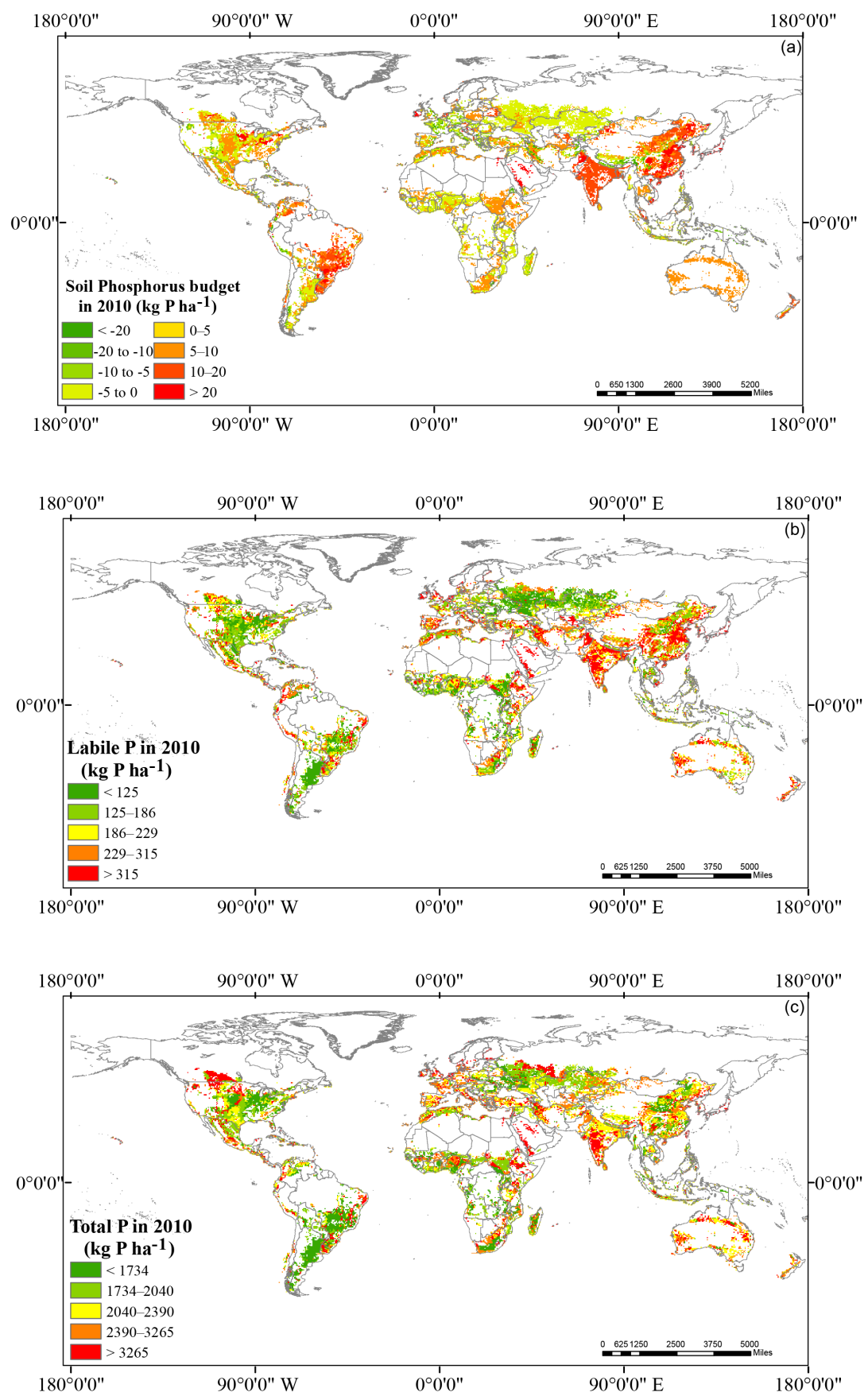

Figure 6. (a) Global soil $\mathrm{P}$ budget in 2010. Soil $\mathrm{P}$ budget is the biogeochemical soil $\mathrm{P}$ budget, which is the difference between total soil $\mathrm{P}$ input (mineral fertilizer, manure, and deposition) and total soil P output (uptake and runoff); the global distribution of (b) labile P (LP) and (c) total P in global agricultural land soils in 2010. Yearly grid maps for the period 1900-2010 can be viewed in movie S5 in the Supplement.

$\mathrm{P}$ uptake and soil $\mathrm{P}$ budget have a large spatial heterogeneity. China, India, and Brazil are among the countries with the highest P input rates in 2010 (Fig. S1a). China, USA, eastern Africa, and western Europe are the areas with the highest P uptake (Fig. S1b). However, South Africa (like Brazil), China, India, and Central America are regions with large
P surpluses. Western Europe, western Russia, and western Africa currently show P deficits (Fig. 6a).

\subsection{Soil P pools}

The spatial distribution of the changes in the LP, SP, and TP $(\mathrm{TP}=\mathrm{LP}+\mathrm{SP})$ pools was generated yearly from $1900 \mathrm{un}-$ 
Table 4. Standardized regression coefficient (SRC) $)^{\mathrm{a}}$ representing the relative sensitivity of the soil LP, SP pools, and crop P uptake to the variation of 12 model parameters. Columns values represent the global model results for the year 1950s and 2000.

\begin{tabular}{lrr|rr|rr}
\hline Parameter & \multicolumn{2}{c|}{ LP } & \multicolumn{2}{c|}{ SP } & \multicolumn{2}{c}{ Uptake } \\
\cline { 2 - 6 } & 1950 & 2000 & 1950 & 2000 & 1950 & 2000 \\
\hline$\mu_{\text {LS }}$ & 0.04 & 0.09 & 0.00 & -0.01 & & 0.05 \\
fr_weathering & 0.04 & 0.04 & 0.01 & 0.02 & & 0.04 \\
agri_2_natural_years & & & & & & \\
max_uptake & -0.07 & -0.12 & -0.03 & -0.05 & $\mathbf{0 . 8 5}$ & $\mathbf{0 . 4 7}$ \\
fr_mobile & -0.03 & -0.11 & -0.01 & -0.03 & $\mathbf{0 . 2 9}$ & $\mathbf{0 . 5 0}$ \\
LP_yang & 1.00 & $\mathbf{0 . 9 6}$ & -0.09 & -0.11 & $\mathbf{0 . 2 3}$ & $\mathbf{0 . 3 7}$ \\
TP_yang & -0.02 & -0.08 & 1.00 & 0.97 & - & -0.03 \\
deposition & & & & & & \\
init_recovery & -0.02 & -0.10 & -0.01 & -0.03 & $\mathbf{0 . 2 9}$ & $\mathbf{0 . 5 1}$ \\
runoff & & & & 0.00 & & \\
fertilizer & 0.06 & $\mathbf{0 . 2 4}$ & 0.02 & 0.10 & 0.03 & 0.18 \\
manure & 0.06 & 0.10 & 0.03 & 0.06 & 0.02 & 0.06 \\
\hline
\end{tabular}

${ }^{a}$ Cells with no value represent insignificant SRC values; all cells with values have significant SRC; numbers with normal font indicate values $-0.2<\mathrm{SRC}<0.2$; and numbers with bold font indicate values $<-0.2$ and $>0.2$. The absolute value of an $\mathrm{SRC}$ value of 0.2 indicates that the parameter concerned has an influence of $0.2^{2}=0.04(4 \%)$ on the model variable considered. We refer to this as an important effect on the model output variable considered. Positive SRC values imply that a higher parameter value yields a higher model output, while negative SRC values indicate an inverse relation between model output and parameter value. The blank cells are not significant. The full results with data for world regions and selected countries are in Table S4.

til 2010. In the initial condition (1900), soils in wet tropical climates generally had low $\mathrm{P}$ levels as a result of prolonged weathering (Yang and Post, 2011) (Fig. S2). Nevertheless, with the advent of intensive agricultural activities during the 20th century and up until 2010, TP has drastically increased along the western coast of the Americas, in central and western India, in the southwest part of Saudi Arabia, and in Ethiopia (Fig. 6c).

The total $\mathrm{P}$ content per hectare increased rapidly between 1900 and 2010 in soils of Europe (31\% relative to 1900), North America (15\%), Asia (17\%), and Oceania (17\%), with a small increase in South America (2\%), while total $\mathrm{P}$ content has been stable in Africa (Fig. 7c). This increase primarily occurred in the decades after 1950.

The labile $\mathrm{P}$ content per hectare of western Europe was relatively stable from 1900 to 1930 (260 to $272 \mathrm{~kg} \mathrm{Pha}^{-1}$ ) and then increased from 1940 to 1970 (314 to $370 \mathrm{~kg} \mathrm{Pha}^{-1}$ ) and decreased from 1980 to 2010 ( 387 to $350 \mathrm{~kg} \mathrm{Pha}^{-1}$ ), due to the decreasing $\mathrm{P}$ fertilizer application rates in recent years. LP in Asia and South America has been increasing, especially since 1980. In Africa, LP has remained consistently stable, while more recently it has become stable in Oceania and North America (Fig. 7a).

It is apparent that some regions had a more favourable starting position in terms of soil $\mathrm{P}$ fertility in 1900 . For example, soil P levels (both total and labile P) in western Europe were much higher than in all the other world regions. With the large surpluses in the period 1960-1980 the soil $\mathrm{P}$ reserves in western Europe even increased and started to decrease in the last decades to a level almost equal to that in
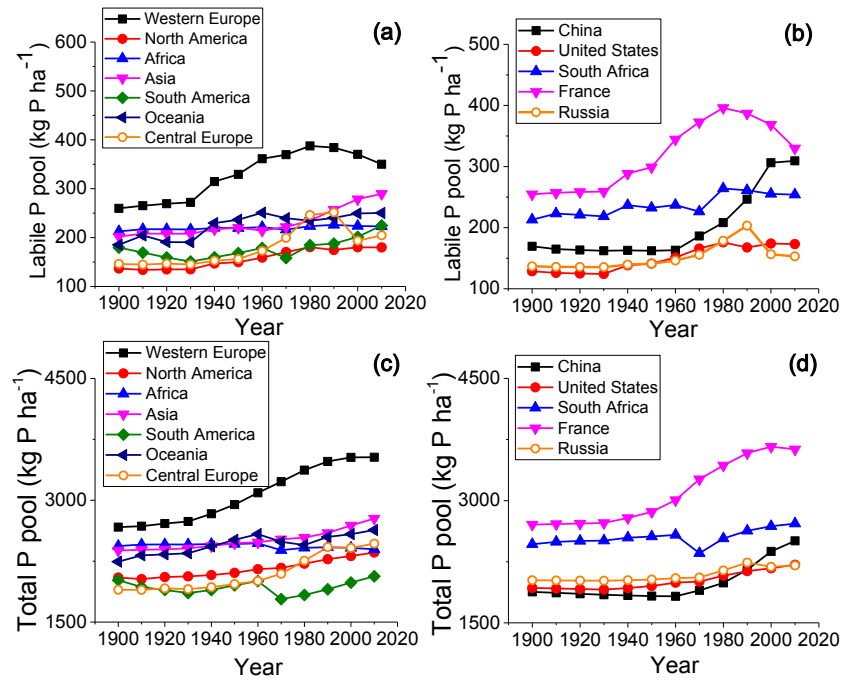

Figure 7. Changes of soil LP (a) in different world regions and (b) in different countries, and TP pools (c) for different world regions and (d) countries in arable land for the period 1900-2010.

China. However, China started from much lower soil P levels and has been accumulating rapidly in a relatively short time period. Other regions like North America started at lower values than western Europe, surpluses have not been as large as in western Europe, and the soil labile and total P has slowly increased. This may explain why, in North America, $\mathrm{P}$ input rates have decreased but to levels that are higher than those in western Europe. 
Table 5. Comparison with other studies for global cropland.

\begin{tabular}{lrrrrr}
\hline Reference & Year & $\begin{array}{c}\text { P fertilizer } \\
\text { application* }\end{array}$ & $\begin{array}{c}\text { Manure P } \\
\text { application* }\end{array}$ & $\begin{array}{r}\text { Crop P } \\
\text { uptake* }\end{array}$ & $\begin{array}{r}\text { Agronomic soil } \\
\text { P budget* }\end{array}$ \\
\cline { 2 - 5 } & \multicolumn{5}{c}{ Tg Pyear $^{-1}$} \\
\hline Sattari et al. (2012) & 2007 & 23.2 & & 11.5 & 11.7 \\
MacDonald et al. (2011) & 2000 & 14.2 & 9.6 & 12.3 & 11.5 \\
Chen and Graedel (2016) & 2013 & 20.2 & 6.5 & 12.4 & 14.3 \\
Bouwman et al. (2009) & 2000 & $>13$ & 7.0 & 10.0 & 11.0 \\
This study & 2000 & 13.6 & 6.1 & 10.7 & 9.0 \\
& 2010 & 15.8 & 7.2 & 12.0 & 11.0 \\
\hline
\end{tabular}

* $\mathrm{P}$ fertilizer application is the application of mineral fertilizer; agronomic soil $\mathrm{P}$ budget is the difference between the sum of $\mathrm{P}$ mineral fertilizer and manure and crop $\mathrm{P}$ uptake (agronomic soil $\mathrm{P}$ budget $=\mathrm{P}$ fertilizer application + manure $\mathrm{P}$ application - crop P uptake).

\section{Discussion}

Sattari et al. (2012) applied the DPPS model to reproduce historical continental crop P uptake (1965-2007) and estimate $\mathrm{P}$ requirements for crop production in 2050 using fixed $\mu_{\mathrm{LS}}$ and $\mu_{\mathrm{SL}}$. Our longer simulation time (1900-2010), as well as spatially explicit calculations $\left(0.5\right.$-by- $0.5^{\circ}$ resolution), allows assessing long-term changes in soil $\mathrm{P}$ pools, taking into account local heterogeneity (Table 1). Further improvements include the consideration of yearly land use changes, spatially explicit soil properties and $\mathrm{P}$ contents, erosion and runoff, the dynamic calculation of transfer time between the soil $\mathrm{P}$ pools, and initialization of different soil $\mathrm{P}$ pools with global data. A final improvement is the calculation of crop uptake using Michaelis-Menten kinetics, whereby the maximum uptake development reflects technological changes such as improved crop varieties (Table 1).

The reason for $\mathrm{P}$ uptake underestimation in regions like western Europe in recent years is that the model is calibrated using fr_mobile over the whole period 1961-2010. Hence, the results for the middle of this period are very close to observed uptake values, but in the early and late part of the period 1961-2010 the model may deviate from the observations. We have deliberately chosen a fixed value of fr_mobile. In theory, fr_mobile could be estimated by using the characteristics of the different fertilizers used, but such data are unavailable at our gridded scale. Furthermore, estimating a time-varying parameter describing $\mathrm{P}$ availability would be extremely complex and falls outside the scope of this study.

The global and country-specific results for $\mathrm{P}$ cycling in croplands of our study agree well with estimates from the the recent literature (Table 5). Large $\mathrm{P}$ surpluses in China, India, and western Europe in our study agree with MacDonald et al. (2011), as well as P deficits in Argentina, the central parts of the United States, and eastern Europe (as well as central Asia). For most provinces in China, especially in eastern China, estimated $\mathrm{P}$ surpluses of $>10 \mathrm{~kg} \mathrm{Pha}^{-1}$ year $^{-1}$ are similar to both Shen et al. (2011) and MacDonald et al. (2011), who reported $>10$ and $>13 \mathrm{~kg} \mathrm{Pha}^{-1} \mathrm{year}^{-1}$, re- spectively (Table 5). Unfortunately, it is not possible to compare our results for the changes in soil $\mathrm{P}$ pools, since all the studies presented in Table 5 have no inventories of changes in soil $\mathrm{P}$ reserves.

In the early 20th century, the P uptake rates are only marginally smaller than the low $\mathrm{P}$ input rates, implying that $\mathrm{P}$ was balanced in crop production systems, albeit producing low yields. $\mathrm{P}$ inputs have steadily increased globally since the 1950s, allowing for an increase in crop production but ultimately leading to a decrease in the efficiency of $\mathrm{P}$ application and an increase in the soil $\mathrm{P}$ reserves. Both our study and those of Sattari et al. $(2012,2016)$ show that, since the 1980s, P application rates have been reduced in much of Europe, while uptake continued to increase due to the supply of residual soil $\mathrm{P}$.

Over the last couple of decades, P management practices have varied widely throughout the globe, leading to different $\mathrm{P}$ input rates, $\mathrm{P}$ pool sizes, and crop uptake rates (Figs. 6, 7). For example, agricultural lands in Africa have increased by more than $40 \%$ in the past 4 decades, while both the labile and stable $\mathrm{P}$ pools have slightly decreased due to negative budgets. This indicates that in Africa there has been a net soil $\mathrm{P}$ depletion in cropland, which may be caused, in spite of the expansion of arable land, by the low $\mathrm{P}$ application rates.

In contrast, $\mathrm{P}$ surpluses in industrialized countries have been decreasing steadily from high values in the 1970s and 1980s towards a small deficit in recent years; a hysteresis effect of uptake is observed, with equal inputs resulting in low (1970s) and high (2010) P uptake, due to a gradual increase of the labile pool over the whole period.

The large $\mathrm{P}$ surpluses in the industrialized countries in the 1970s and 1980s represent a legacy for future productive capacity. The present situation in many industrialized countries shows that the $\mathrm{P}$ fertilizer inputs and $\mathrm{P}$ surpluses can be reduced considerably and the phosphorus use efficiency can be increased to high levels without a yield penalty. This phenomenon of the legacy of residual soil $\mathrm{P}$ due to large P surpluses - such as during the 1970s and 1980s in western and eastern Europe, the former Soviet Union, and the USA - has 
also been recognized before (Sattari et al., 2012). The data for the industrialized countries show that this soil P depletion can continue for many years without yield declines. However, the inputs have been reduced to low levels and surpluses turned into deficits, and the current model can eventually be used to investigate how long this depletion can continue without a yield penalty by $\mathrm{P}$ limitation.

China and India have shown large surpluses of $\mathrm{P}$ in particular since the 1990s and are currently building up large soil $P$ reserves, albeit heterogeneously distributed with negative budgets in some parts. In 2010, the residual soil $\mathrm{P}$ in China and India was 18 and $17 \mathrm{~kg} \mathrm{Pha}^{-1}$ year $^{-1}$, respectively, compared to $1 \mathrm{~kg} \mathrm{Pha}^{-1}$ year $^{-1}$ in the USA. The total accumulated residual $\mathrm{P}$ per hectare of cropland in China and India exceeds that in western Europe, the Russian Federation, and the USA, suggesting that it may be possible to reduce $\mathrm{P}$ application rates without affecting crop uptake.

There are many factors that drive the spatiotemporal distribution of soil phosphorus in global cropland, including the natural soil biogeochemical background, soil properties, farming practices (mainly the increasing input of anthropogenic $\mathrm{P}$ fertilizer application), land use and land cover change (arable land expansion or abandonment and changes in crop species composition), $\mathrm{P}$ losses through soil erosion, soil temperature and soil water content, soil microbial ecosystem, and crop production. Ringeval et al. (2017) qualified the contribution of these different factors to the global soil P distribution and found that soil biogeochemical background and farming practices are the most important drivers for $\mathrm{P}$ uptake. This agrees with our focus on these factors as the biggest controllers for $\mathrm{P}$ distribution in cropland soils. The $\mathrm{P}$ content of soils under natural vegetation and the $\mathrm{CaCO}_{3}$ content, $\mathrm{pH}$, clay, moisture, and water content determine the capacity for $\mathrm{P}$ sorption, retention, and soil weathering. For example, in arid and semi-arid regions the low level of soil water content hinders $\mathrm{P}$ diffusion and plant root growth, ultimately limiting crop $\mathrm{P}$ uptake. While this chemical background is highly heterogeneous, our gridded approach and model initialization capture some of these differences in global soils by distributing LP and SP according to natural soils of Yang et al. (2013). Farming practices, especially dramatically increasing $P$ fertilizer and manure application rates, have an important impact on the spatiotemporal changes of soil $\mathrm{P}$ and crop uptake (Figs. 2 and 7).

The contribution of expanding cropland areas and crop yields (P uptake per hectare) to the production increase since 1960 is about $18 \%$ for the former and $82 \%$ for the latter. Nevertheless, there are likely regional differences, with developing countries having a greater proportion of agricultural areal expansion and industrialized countries more improvements in nutrient use efficiency (Fig. 4). This explains why for example in Africa the labile and total $P$ pools per hectare have been relatively constant, while uptake has exceeded inputs during the whole period 1900-2010.

\section{Concluding remarks}

This study presents a spatially explicit model-based inventory of global soil P stocks and crop uptake for the period of 1900-2010, which represents the years in the Anthropocene when human activities accelerated the global agricultural $P$ cycle by more than a factor of 10 . The spatially explicit DPPS model enables matching local soil $\mathrm{P}$ pools with crop $\mathrm{P}$ uptake for the past century with a high resolution $\left(0.5\right.$ by $\left.0.5^{\circ}\right)$ while accounting for finer-scale heterogeneity by including land use change within grid cells. Compared with previous non-spatial DPPS application by Sattari et al. (2012), our research has improved DPPS in calculating the spatial variability of the soil P pool changes within countries by accounting for soil characteristics and dynamic parameters, calculating the process-based uptake rather than fixed value, considering the yearly land use change, initializing different soil P pools with global data, and modelling P losses by runoff instead of fixed numbers.

Global $\mathrm{P}$ inputs (including mineral fertilizer and manure) have increased from $2.0 \mathrm{Tg} \mathrm{Pyear}^{-1}$ in 1900 to 23.0 $\mathrm{Tg} \mathrm{\textrm {P } _ { \text { year } }}{ }^{-1}$ in 2010 with large variation across different regions and countries of the world. At the global scale, about half of the applied P in 2010 was taken up by harvested crops (modelled annual rates of $12 \mathrm{Tg} \mathrm{Pyear}^{-1}, 7.3 \mathrm{~kg} \mathrm{Pha}^{-1}$; data of $13.8 \mathrm{Tg} \mathrm{P}_{\text {year }}{ }^{-1}, 8 \mathrm{~kg} \mathrm{Pha}^{-1}$ ). All world regions and countries show similar patterns before 1950 , i.e. very low $P$ input levels and crop P uptake that are not very different from inputs. However, after 1950, regions and countries show different soil P inputs, crop P uptake, soil P budgets, and pool changes, which indicate the spatial and temporal variability of soil $\mathrm{P}$ condition.

According to the model sensitivity analysis (Table 4), the maximum uptake level (max_uptake, reflecting the level of technology), the initial labile pool size (LP_yang), the calibration coefficient which mimics the direct $P$ availability within the labile pool (fr_mobile), and the slope of the P input response curve at the origin (init_recovery) have an important influence on crop P uptake. This means that the simulated crop $\mathrm{P}$ uptake is influenced by both soil properties and crop characteristics.

The DPPS model can be used to assess the long-term changes in the soil P status, an important indicator of soil fertility, future soil productivity, and food security. Via its gridded approach, DPPS can ultimately help to improve our mechanistic understanding of the P cycle in global cropland at the local and global scale and our ability to evaluate broadscale food security and make sustainable P management policies.

Data availability. The results of the sensitivity analyses and all data underlying figures and maps are available in the Supplement. 


\section{The Supplement related to this article is available online at doi:10.5194/bg-14-2055-2017-supplement.}

Competing interests. The authors declare that they have no conflict of interest.

Acknowledgements. We gratefully acknowledge the support from the China 973 project 2013CB956601, CNSF\#41371491 for Chaoqing $\mathrm{Yu}$, and financial support from the China Scholarship Council for Jie Zhang. We gratefully acknowledge financial support from EU H2020 (MSCA award 661163 to José M. Mogollón). Alexander F. Bouwman and Arthur H. W. Beusen received support from PBL Netherlands Environmental Assessment Agency through in-kind contributions to The New Delta 2014 ALW project no. 869.15.015 (The role of rivers in the global carbon cycle under global change: effects of hydrology and nutrient loads on methane and carbon dioxide emissions) and no. 869.15.014 (Modelling past, present and future nutrient stoichiometry of river-impacted coastal systems: advancing understanding and quantification of eutrophication from the local to global scale).

Edited by: M. Weintraub

Reviewed by: W. Shangguan and one anonymous referee

\section{References}

Alexandratos, N. and Bruinsma, J.: World agriculture towards 2030/2050. The 2012 revision, Food and Agriculture Organization of the United Nations, RomeESA Working Paper No. 12-03, 2012.

Batjes, N. H.: Global distribution of soil phosphorus retention potential, ISRIC - Worls Soil Information, WageningenISRIC Report 2011/06, 41, 2011.

Beaton, J.: Efficient use of fertilizer use manual: History, available at: http://academic.uprm.edu/dsotomayor/agro6505/History_of_ Fertilizer_Beaton.pdf (last access: 1 September 2016), Mosaic (http://mosaicco.com), 2006.

Beusen, A. H. W., Van Beek, L. P. H., Bouwman, A. F., Mogollón, J. M., and Middelburg, J. J.: Coupling global models for hydrology and nutrient loading to simulate nitrogen and phosphorus retention in surface water - description of IMAGE-GNM and analysis of performance, Geosci. Model Dev., 8, 4045-4067, doi:10.5194/gmd-8-4045-2015, 2015.

Beusen, A. H. W., Bouwman, A. F., Van Beek, L. P. H., Mogollón, J. M., and Middelburg, J. J.: Global riverine N and P transport to ocean increased during the 20th century despite increased retention along the aquatic continuum, Biogeosciences, 13, 24412451, doi:10.5194/bg-13-2441-2016, 2016.

Bouwman, A., Beusen, A., and Billen, G.: Human alteration of the global nitrogen and phosphorus soil balances for the period 1970-2050, Global Biogeochem. Cy., 23, GB0A04, doi:10.1029/2009GB003576, 2009.

Bouwman, A. F., Klein Goldewijk, K., Van der Hoek, K. W., Beusen, A. H. W., Van Vuuren, D. P., Willems, W. J., Rufino, M. C., and Stehfest, E.: Exploring global changes in nitrogen and phosphorus cycles in agriculture induced by livestock production over the 1900-2050 period, P. Natl. Acad. Sci. USA, 110, 20882-20887, doi:10.1073/pnas.1012878108, 2013.

Brady, N. C.: The nature and properties of soils, Macmillan Publishing Company, New York, 1990.

Cerdan, O., Govers, G., Le Bissonnais, Y., Van Oost, K., Poesen, J., Saby, N., Gobin, A., Vacca, A., Quinton, J., Auerswald, K., Klik, A., Kwaad, F. J. P. M., Raclot, D., Ionita, I., Rejman, J., Rousseva, S., Muxart, T., Roxo, M. J., and Dostal, T.: Rates and spatial variations of soil erosion in europe: A study based on erosion plot data, Geomorphology, 122, 167-177, doi:10.1016/j.geomorph.2010.06.011, 2010.

Chen, M. and Graedel, T.: A half-century of global phosphorus flows, stocks, production, consumption, recycling, and environmental impacts, Global Environ. Change, 36, 139-152, 2016.

Cordell, D., Drangert, J.-O., and White, S.: The story of phosphorus: Global food security and food for thought, Global Environ. Change, 19, 292-305, doi:10.1016/j.gloenvcha.2008.10.009, 2009.

Cressy Morrison, A.: Man in a chemical world, The service of chemical industry, C. Scribner's Sons, Ltd, New York, 1937.

Fairhurst, T., Lefroy, R., Mutert, E., and Batjes, N.: The importance, distribution and causes of phosphorous deficiency as a constraint to crop production in the tropics, Agroforestry Forum, 9, 2-8, 1999.

FAO: Yearbook of food and agricultural statistics, Production 1950 volume iv, part i, Food and Agriculture Organization of the United Nations, Washington, D.C., 1951.

FAO: Faostat database collections, Data on fodder crops from production - crops - crops primary $>$ list - production quantity, available at: http://faostat.Fao.Org/site/567/default.Aspx\#ancor (last access: 18 January 2016), Food and Agriculture Organization of the United Nations, Rome, 2016a.

FAO: Faostat database collections, All crop production and livestock except fodder crops retrieved, available at: http://www.fao. org/faostat/en/\#home (last access: 18 January 2016), Food and Agriculture Organization of the United Nations, Rome, 2016b.

FAO-Unesco: Soil map of the world, FAO, Rome, Italy, 1974.

Hart, M. R., Quin, B. F., and Nguyen, M. L.: Phosphorus runoff from agricultural land and direct fertilizer effects: A review, J. Environ. Qual., 33, 1954-1972, 2004.

Janssen, B. H., Lathwell, D. J., and Wolf, J.: Modeling long-term crop response to fertilizer phosphorus. Ii. Comparison with field results, Agron. J., 79, 452-458, 1987.

Klein Goldewijk, K., Beusen, A., and Janssen, P.: Long-term dynamic modeling of global population and built-up area in a spatially explicit way: Hyde 3.1, Holocene, 20, 565-573, 2010.

Klein Goldewijk, K., Beusen, A., Van Drecht, G., and De Vos, M.: The hyde 3.1 spatially explicit database of human-induced global land-use change over the past 12,000 years, Global Ecol. Biogeogr., 20, 73-86, doi:10.1111/j.1466-8238.2010.00587.x, 2011

Koning, N., Van Ittersum, M., Becx, G., Van Boekel, M., Brandenburg, W., Van Den Broek, J., Goudriaan, J., Van Hofwegen, G., Jongeneel, R., and Schiere, J.: Long-term global availability of food: Continued abundance or new scarcity?, NJAS-Wageningen Journal of Life Sciences, 55, 229-292, 2008.

Liu, Y., Villalba, G., Ayres, R. U., and Schroder, H.: Global phosphorus flows and environmental impacts from a consump- 
tion perspective, J. Ind. Ecol., 12, 229-247, doi:10.1111/j.15309290.2008.00025.x, 2008.

MacDonald, G. K., Bennett, E. M., Potter, P. A., and Ramankutty, N.: Agronomic phosphorus imbalances across the world's croplands, P. Natl. Acad. Sci. USA, 108, 3086-3091, doi:10.1073/pnas.1010808108, 2011.

Mahowald, N., Jickells, T. D., Baker, A. R., Artaxo, P., BenitezNelson, C. R., Bergametti, G., Bond, T. C., Chen, Y., Cohen, D. D., Herut, B., Kubilay, N., Losno, R., Luo, C., Maenhaut, W., McGee, K. A., Okin, G. S., Siefert, R. L., and Tsukuda, S.: Global distribution of atmospheric phosphorus sources, concentrations and deposition rates, and anthropogenic impacts, Global Biogeochem. Cy., 22, GB4026, doi:10.1029/2008GB003240, 2008.

McDowell, R. W. and Sharpley, A. N.: Approximating phosphorus release from soils to surface runoff and subsurface drainage, J. Environ. Qual., 30, 508-520, 2001.

Michaelis, L. and Menten, M. L.: Die kinetik der invertinwirkung, Biochem. Z, 49, 352, 1913.

Mitchell, B. R.: International historical statistics, the americas: 1750-1988, MacMillan, Indianapolis, 817 pp., 1993a.

Mitchell, B. R.: International historical statistics, africa, asia \& oceania: 1750-1993, 3rd Edn., MacMillan, Indianapolis, 1113 pp., $1993 b$.

Mitchell, B. R.: International historical statistics, europe: 17501993, 4th Edn., MacMillan, Indianapolis, 817 pp., 1998.

Nijland, G. O., Schouls, J., and Goudriaan, J.: Integrating the production functions of liebig, michaelis-menten, mitscherlich and liebscher into one system dynamics model, NJAS-Wageningen Journal of Life Sciences, 55, 199-224, 2008.

Potashcorp: Overview of potashcorp and its industry, available at: http://www.potashcorp.com/overview/nutrients/phosphate/ overview/world-phosphate-fertilizer-use-crop-region (last access: 25 October 2016), 2016.

Ringeval, B., Augusto, L., Monod, H., van Apeldoorn, D., Bouwman, L., Yang, X., Achat, D. L., Chini, L. P., Van Oost, K., and Guenet, B.: Phosphorus in agricultural soils: Drivers of its distribution at the global scale, Glob. Change Biol., doi:10.1111/gcb.13618, online first, 2017.

Sattari, S. Z., Bouwman, A. F., Giller, K. E., and van Ittersum, M. K.: Residual soil phosphorus as the missing piece in the global phosphorus crisis puzzle, P. Natl. Acad. Sci. USA, 109, 63486353, 2012.
Sattari, S. Z., Bouwman, A. F., Martinez Rodriguez, R., Beusen, A. H. W., and van Ittersum, M. K.: Negative global phosphorus budgets challenge sustainable intensification of grasslands, Nat. Commun., 7, 10696, doi:10.1038/ncomms10696, 2016.

Shen, J., Yuan, L., Zhang, J., Li, H., Bai, Z., Chen, X., Zhang, W., and Zhang, F.: Phosphorus dynamics: From soil to plant, Plant Physiol., 156, 997-1005, 2011.

Syers, J. K., Johnston, A. A., and Curtin, D.: Efficiency of soil and fertilizer phosphorous use. Reconciling changing concepts of soil phosphorous behaviour with agronomic information, Food and Agriculture Organization of the United Nations (FAO), RomeFertilizer and Plant Nutrition Bulletin 18, 110, 2008.

Tarkalson, D. D. and Mikkelsen, R. L.: Runoff phosphorus losses as related to soil test phosphorus and degree of phosphorus saturation on piedmont soils under conventional and no-tillage, Commun. Soil Sci. Plan., 35, 2987-3007, 2004.

UN: World population prospects: The 2015 revision, UN, Department of economic and social affairs, New York, available at: http://esa.un.org/unpd/wpp/ (last access: 12 April 2017), 2016.

Van Grinsven, H. J. M., Bouwman, L., Cassman, K. G., Van Es, H. M., McCrackin, M. L., and Beusen, A. H. W.: Losses of ammonia and nitrate from agriculture and their effect on nitrogen recovery in the european union and the united states between 1900 and 2050, J. Environ. Qual., 44, 356-367, doi:10.2134/jeq2014.03.0102, 2015.

Van Kauwenbergh, J.: World phosphorus rock reserves and resources, International Fertilizer Development Center, Muscle Shoals, ALTechnical Bulletin IFDC-T-75, 2010.

Van Vuuren, D. P., Bouwman, A. F., and Beusen, A. H. W.: Phosphorus demand for the 1970-2100 period: A scenario analysis of resource depletion, Global Environ. Change, 20, 428-439, doi:10.1016/j.gloenvcha.2010.04.004, 2010.

Wolf, J., De Wit, C., Janssen, B. H., and Lathwell, D. J.: Modeling long-term crop response to fertilizer phosphorus, I. The model, Agron. J., 79, 445-451, 1987.

Yang, X. and Post, W. M.: Phosphorus transformations as a function of pedogenesis: A synthesis of soil phosphorus data using Hedley fractionation method, Biogeosciences, 8, 2907-2916, doi:10.5194/bg-8-2907-2011, 2011.

Yang, X., Post, W. M., Thornton, P. E., and Jain, A.: The distribution of soil phosphorus for global biogeochemical modeling, Biogeosciences, 10, 2525-2537, doi:10.5194/bg-10-2525-2013, 2013. 